\title{
Andrographolide Ameliorate Rheumatoid Arthritis by Promoting the Development of Regulatory T Cells
}

\author{
Muhaimin Rifa'i* \\ Biology Department, Brawijaya University, Jl. Veteran, Malang 65145, East Java, Indonesia
}

\begin{abstract}
Andrographolide is important material present in Andrographis paniculata. This material can promote T cell to develop into regulatory $\mathrm{T}$ cell, $\mathrm{CD} 4{ }^{+} \mathrm{CD} 25^{+}$. $\mathrm{CD} 4{ }^{+} \mathrm{CD} 25^{+}$regulatory $\mathrm{T}\left(\mathrm{T}_{\text {reg }}\right)$ cells, a component of the innate immune response, which play a key role in the maintenance of self-tolerance, have become the focus of numerous studies over the last decade. These cells have the potential to be exploited to treat autoimmune disease. These cells inhibit the immune response in an Ag-nonspecific manner, interacting with other' $\mathrm{T}$ cells. These $\mathrm{T}$ cell populations actively control the properties of other immune cells by suppressing their functional activity to prevent autoimmunity but also influence the immune response to allergens as well as against tumor cells and pathogens. In this experiment we showed that active compound from Andrographis paniculata namely andrographolide can induce active regulatory $T$ cell that has an efficacy to cure rheumatoid arthritis mice model.
\end{abstract}

Keywords: Andrographolide; Andrographis sp; Regulatory T cells; Rheumatoid arthritis

\section{Introduction}

Andrographolide is the main labdane diterpene present in Andrographis paniculata. Two lines of evidence report immunostimulant and anti-inflammatory properties for andrographolide in different models. In the other hand is known that $\mathrm{CD}^{+}{ }^{+} \mathrm{CD} 25^{+}$ regulatory $\mathrm{T}$ cells can protect an individual from autoimmune diseases. There is some evidence that $\mathrm{CD}^{+}{ }^{+} \mathrm{CD} 25^{+}$regulatory $\mathrm{T}$ cells have an ability to prevent the development of autoreactive cells. In human, $\mathrm{CD} 8^{+} \mathrm{CXCR} 3^{+}$ cells are believed to be a regulatory $\mathrm{T}$ cells that has the same ability with $\mathrm{CD} 4{ }^{+} \mathrm{CD} 25^{+}$in mice $[1-5,10,19]$.

Rheumatoid arthritis (RA) is a chronic inflammatory disorder that ultimately leads to the destruction of joint architecture. The pathogenic events that lead to the development of RA are not fully understood, although the presence of inflammatory cytokines has been well documented to play a key role in the

\footnotetext{
*Corresponding address:

Muhaimin Rifa'i

Biology Department, Brawijaya University

Jl. Veteran, Malang 65145,

East Java, Indonesia

Email : rifa123@ub.ac.id
}

induction and maintenance of this disease [1621]. This disease attacked around $1 \%$ population of the world that appear in people in the aged of 25-50 years, but did not close the possibility that people in any ages can suffer that disease. Rheumatoid arthritis is a degenerative disease that mostly attacks women. It is thought that various factors including genetic elements have a significant contribution to the emergence of this disease.

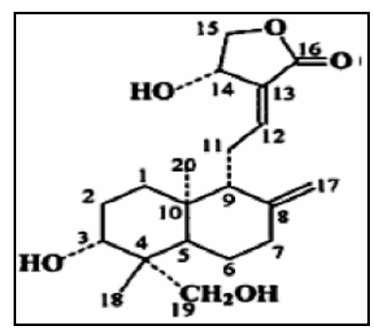

Molecular structure of andrographolide

Rheumatoid arthritis treatment is usually done by resting the affected joint and consumes synthetic drugs. Treatment is often only relieve pain and prevent inflammation. Drugs that have been used for pain relieve and prevention of inflammation is non-steroidal drug, antiinflammatory (aspirin and ibuprofen), slowacting drugs, penicillamine, corticosteroids, and immunosuppressive drugs. The use of these 
drugs in the long term will be very harmful and cause various side effects that involve almost every organ $[6-18,20,21]$. Because of serious impacts resulting from the rheumatoid arthritis treatment, it is necessary to include prevention efforts that can normalize cell homeostasis. In this study we tested herbs that rich andrographolide, the material containing active compound to induce regulatory $\mathrm{T}$ cells.

\section{Materials and methods}

Mice was intravenously injected with CFA (complete Freund's adjuvant) of $75 \mu \mathrm{l}$, then performed a second booster in mice feet by 75 $\mu \mathrm{l}$ (each leg of $35.5 \mu \mathrm{l}$ ). Observations were made every day to see the swelling of the feet. This treated mice is used as a model of rheumatoid arthritis (RA). Mice model of RA are intraperitoneally injected with $100 \mu \mathrm{l}$ or $400 \mu \mathrm{l}$ substrate of Andrographis paniculata that contain andrographolide.

\section{Result and Discussion}

Andrographolide derived from Andrographis paniculata is a medicinal compound which can stimuli the expression of CD25 molecules on T cells. CD25 molecule expression on CD4 T cells is one marker of the cell with the nature of the regulatory function. In RA mice the number of regulatory $T$ cells is increased but cannot overcome the disease. Intrapetoneally injection of andrographolide $(100 \mu \mathrm{l}$ and $400 \mu \mathrm{l})$ isolated from Andrographis paniculata can increase the number of regulatory $\mathrm{T}$ cells dramatically (Figure. 1).

Intraperitoneally injection of andrographolide compound in RA mice model can ameliorate the disease and do not affect the ratio of limfoid cell signifantly. In this experiment we clearly showed that $\mathrm{T}$ cells which is analized from spleen looks normal in when treated with andrographolide $(100 \mu \mathrm{l}$ and $400 \mu \mathrm{l})$. This meant that andrographolide compound have an efficacy to cure RA mice model without interfering $\mathrm{T}$ cell condition (Figure. 2). After we know that the number of $T$ cell lymphocytes do not affected by the treatment we examine

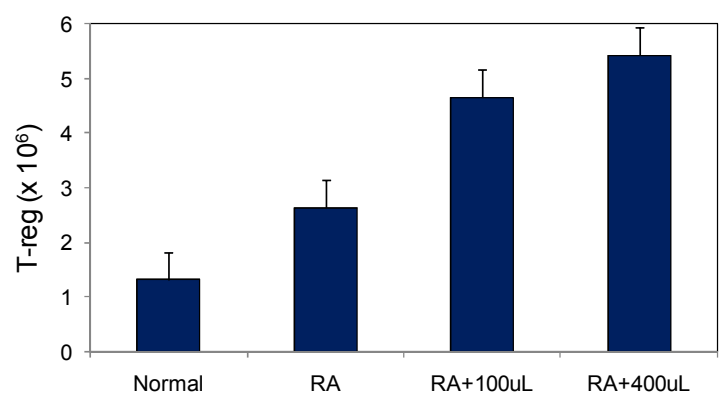

Figure 1. $\mathrm{CD}^{+} \mathrm{CD}^{+} 5^{+}$cells increased in $\mathrm{RA}$ mice that received injections of andrographolide derived from Andrographis paniculata substrate $(100 \mu 1$ and $400 \mu l)$. The bars are calculation of the number of CD4 $\mathrm{T}$ cells expressing positive CD25 molecules on the spleen cells of mice that had been injected with andrographolide $(100 \mu \mathrm{l}$ and $400 \mu \mathrm{l})$ derived from Andrographis paniculata. Analysis was carried out seven weeks post treatment. The two first bars on the left are controls for comparison. Data are mean $\pm \mathrm{SD}$ values of three independent experiments $(P<0.01)$.

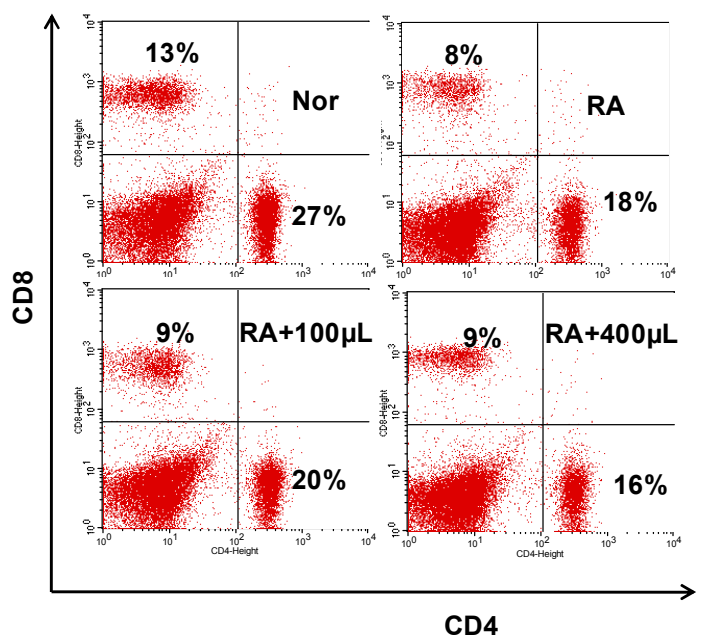

Figure 2. The presence andrographolide do not interfere with homeostasis in mice. Spleen cells is labeled with anti-CD4-FITC and anti-CD8-PE antibodies. Adding andrographolide material compound isolated from Andrographis paniculata $(100 \mu \mathrm{l}$ and $400 \mu \mathrm{l})$ in mice does not affect the amount of $\mathrm{CD}^{+}$and $\mathrm{CD}^{+} \mathrm{T}$ cells in RA mice models. Upper left panel (Nor $=$ normal individuals), and the upper right panel ( $\mathrm{RA}=$ rheumatoid arthritis models). Data are representative of three independent experiment.

the status of these cells. The data showed that ameliorated mice by andrographo lide compound are associated with an increased number of naïve $\mathrm{T}$ cells marked with $\mathrm{CD} 62 \mathrm{~L}$ (Figue 3). RA mice model showed the decrease of naïve $\mathrm{T}$ cells. This naive $\mathrm{T}$ cells increase when andrographolide material compound is intraperitoneally injected. From the emerged data can be explained that RA model mice rich memory and activated cell that disturb the mice health. 


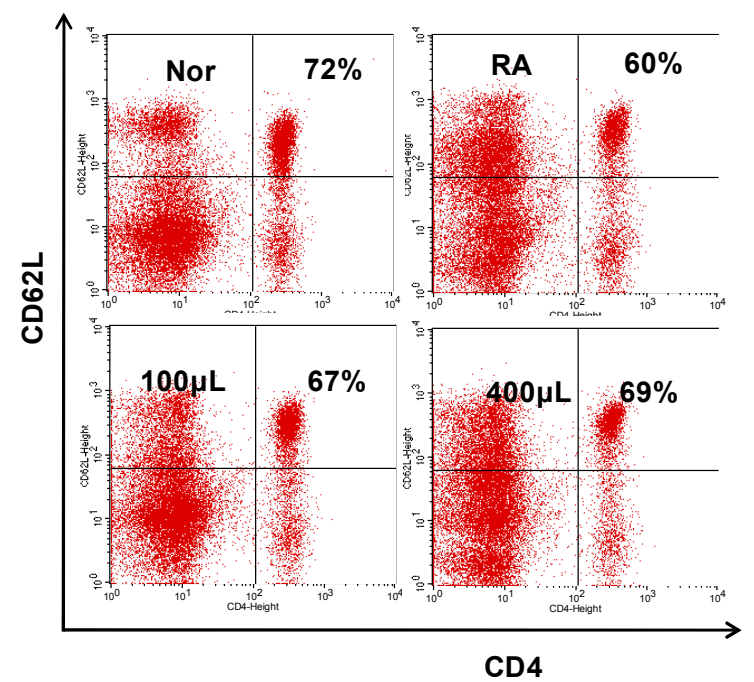

Figure 3. The expression of CD62L is decreased in mice model of RA. Spleen cell was obtained from RA mice seven weeks after treated with andrographolide derived from Andrographis paniculata. Upper left panel is a control that shows the expression of $\mathrm{CD}^{+} \mathrm{CD} 62 \mathrm{~L}^{+}$molecules and the right panel showed the decreased level of $\mathrm{CD} 4^{+} \mathrm{CD} 62 \mathrm{~L}^{+}$in RA mice model. Injection of andrographolide $(100 \mu \mathrm{l}$ and $400 \mu \mathrm{l})$ were shown at the bottom left and right panel, respectively. Data are representative of three independent experiments.

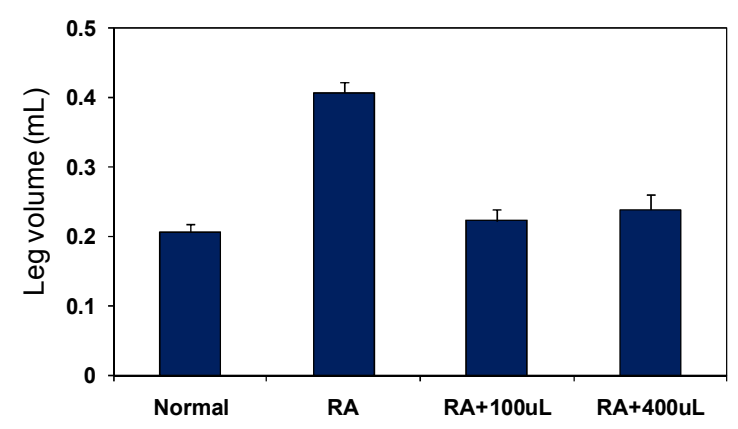

Figure 4. Mice with rheumatoid arthritis (RA) experienced swelling in the joints. The first bar is normal control. Second bar is RA mice model without treatment and other bars are RA model mice treated with andrographolide derived from Andrographis paniculata. $(100 \mu \mathrm{l}$ and $400 \mu \mathrm{l})$. This experiment shows that RA mice feet have swollen twice larger compared with normal mice. Injection of andrographolide can cure RA mice become normal phenotype. Data are mean \pm SD values of three independent experiments $(P<0.01)$.

In this study, swelling of the soles of the feet is measured by measuring the increase of foot volume or inflammation. In this experiment we found that injection of andrographolide derived from Andrographis paniculata can improve the health condition of RA mice model. RA mice model shows swollen legs and this condition can be overcome by injection of andrographolide derived from Andrographis paniculata (Figure 4).

To test whether andrographolide has a toxic effect on the treated mice, we conducted bioassays by measuring the weight of each treatment compared with control. In this study, the data indicate that the dose of $100 \mu \mathrm{l}$ and $400 \mu \mathrm{l}$ is a safe dose. Injection at $100 \mu \mathrm{l}$ and $400 \mu \mathrm{l}$ shows no physiological disorder that remained normal weight mice. Similarly, the observation of liver cells (unpublished data) showed no toxic effect on treatment with andrographolide (Figure 5).

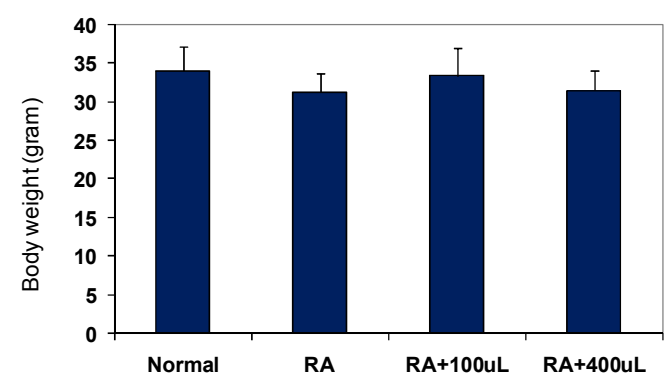

Figure 5. Andrographolide does not show toxic effects in animal models of RA. The body weight of mice are measured 7 weeks after treatment. Data are mean \pm SD values of three independent experiments $(P<0.01)$.

\section{Conclussion}

Andrographolide which is exist in Andrographis paniculata has significant benefits for increasing the number of sets of $\mathrm{CD} 4{ }^{+} \mathrm{CD} 25^{+}$ regulatory $\mathrm{T}$ cells. Increased $\mathrm{CD} 4{ }^{+} \mathrm{CD} 25^{+}$ regulatory $\mathrm{T}$ cells will help to cure rheumatoid arthritis. In mice model of rheumatoid arthritis, $\mathrm{CD} 4{ }^{+} \mathrm{CD} 25^{+}$regulatory $\mathrm{T}$ cell play important role to inhibit the development of effectors $\mathrm{T}$ cells and prevent the development of inflammation in the joints. The generation of $\mathrm{CD} 4{ }^{+} \mathrm{CD} 25^{+}$regulatory can be induced by intraperitoneal injection with andrographolide. Induced $\mathrm{CD}^{+} \mathrm{CD} 25^{+}$regulatory $\mathrm{T}$ cell can ameliorate mice model of rheumatoid arthritis.

\section{Acknowledgements}

We thank to Ulil and Nurvalina for experimental help. We would like to thank Yuda and Wibi for their technical assistance specially of the flow cytometry facility. This work is supported by Directorate General of Higher Education, Ministry of National Education. Grants No: 0174.0/023-04.2/XV/2009 


\section{References}

[1] Zhe S, Yusuke O, Muhaimin R, Agustina T.E, Kazuyuki A, K. Isobe, Suzuki. Human $\mathrm{CD}^{+}{ }^{+} \mathrm{CXCR}^{+}{ }^{+} \mathrm{T}$ cells have the same function as murine $\mathrm{CD} 8{ }^{+} \mathrm{CD} 122^{+}$Treg, Europ J. Immunol 2009; 39:2106-2119.

[2] Rifa’i M, Kawamoto Y, Nakashima I, Suzuki H. Essential Roles of $\mathrm{CD}^{+}{ }^{+} \mathrm{CD} 122^{+}$Regulatory $\mathrm{T}$ cells in the Maintenance of T Cell Homeostasis, J Exp Med 2004; 9:1123-1134.

[3] Amelsfort Jm, Jacobs KM, Bijlsma JW, Lafeber FP, Taams LS. $\mathrm{CD}^{+}{ }^{+} \mathrm{CD} 25^{+}$regulatory $\mathrm{T}$ cells in rheumatoid arthritis, Differences in the presence, phenotype, and function between peripheral blood and synovial fluid, Artbritis Rheum 2004; 50:27752785.

[4] Bleesing M.R, Brown S.E, Straus J.K, Dale R.M, Siegel, M. Johnson, Immunophenotypic profiles in families with autoimmune lymphoproliferative syndrome, Blood 2001; 98:2466-2473.

[5] Chatenoud L, Salomon B, Bluestone JA, Suppressor T cells--they're back and critical for regulation of autoimmunity. Immunol. Rev 2001; 182:149-163.

[6] Chen W., W. Jin, N. Hardegen, K.J. Lei, L. Li, N. Marinos. Conversion of peripheral $\mathrm{CD} 4{ }^{+} \mathrm{CD} 25-$ naive $\mathrm{T}$ cells to $\mathrm{CD} 4{ }^{+} \mathrm{CD} 25^{+}$regulatory $\mathrm{T}$ cells by TGFbeta induction of transcription factor Foxp3, $J$ Exp Med 2003; 198:1875-1886.

[7] Malek TR, Bayer AL. Tolerance, not immunity, crucially depends on IL-2, Nat Rev Immunol 2004; 4:665-674.

[8] Mcgargill MA, Sharp LL, Bui JD, Hedrick SM, Calbo S. Active $\mathrm{Ca}^{+} /$Calmodulin-Dependent Protein Kinase II \{gamma\}B Impairs Positive Selection of T Cells by Modulating TCR Signaling, J Immunol 2005; 175:656-664.

[9] Najafian N, T Chitnis AD Salama B, Zhu C, Benou X, Yuan Mr, Clarkson, Sayegh, A Khoury SJ, Regulatory functions of $\mathrm{CD} 8^{+} \mathrm{CD} 28^{-} \mathrm{T}$ cells in an autoimmune disease model, J. Clin. Invest 2003; 112: 1037-1048.

[10] Papiernik M, DE Moraes M L, Pontoux C, Vasseur F, Penit C. Regulatory CD4 T cells: expression of IL-2R $\alpha$ chain, resistance to clonal deletion and IL-2 dependency, Int. Immunol 1998; 10: 371-378.
[11] Rifa'i M, Z Shi, SY Zhang, YH Lee, H Shiku, K Isobe, $\quad \mathrm{H} \quad$ Suzuki. 2008 $\mathrm{CD} 8{ }^{+} \mathrm{CD} 122^{+}$regulatory $\mathrm{T}$ cells recognize activated $\mathrm{T}$ cells via conventional MHC class I- $\alpha \beta$ TCR interaction and become IL-10-producing active regulatory cells

International immunology 20 (7), 937-947.

[12] Seddon B, Mason D. The third function of the thymus, Immunol. Today 2000; 21: 95-99.

[13] Suciu-Foca N, Manavalan, Cortesini R. Generation and function of antigen-specific suppressor and regulatory T cells, Transpl. Immunol 2003; 11: 235-244.

[14] Takahashi T, Tagami T, Yamazaki S, Uede T, Shimizu, J, Sakaguchi N, Mak TW, Sakaguchi S. Immunologic self-tolerance maintained by $\mathrm{CD} 25^{+} \mathrm{CD}^{+}$regulatory $\mathrm{T}$ cells constitutively expressing cytotoxic $\mathrm{T}$ lymphocyte-associated antigen 4, J. Exp. Med 2000; 192: 303-310.

[15] Thornton AM, Shevach EM. Suppressor effector function of $\mathrm{CD}^{+}{ }^{+} \mathrm{CD} 25^{+}$immunoregulatory $\mathrm{T}$ cells is antigen nonspecific, J. Immunol 2000; 164: 183-190.

[16] Von Herrath BM, Sullivan A, Juedes SJ, Szabo, Glimcher LH. Antigen-driven effector CD8 T cell function regulated by T-bet, Proc. Natl. Acad. Sci. USA 2003; 100: 15818-15823.

[17] Von Herrath MG, Harrison LC. Antigen-induced regulatory $\mathrm{T}$ cells in autoimmunity, Nat. Rev. Immunol 2003; 3: 223-232.

[18] Wan Y, Flavell RA. Identifying Foxp3-expressing suppressor $\mathrm{T}$ cells with a bicistronic reporter, Proc Natl Acad Sci USA 2005; 102: 5126-5131.

[19] Yudoh K, Matsuno H, Nakazawa F, Yonezawa T, Kimura. Reduced expression of the regulatory $\mathrm{CD}^{+}$ $\mathrm{T}$ cell subset is related to Th1/Th2 balance and disease severity in rheumatoid arthritis, Arthritis Rheum 2000; 43: 617-627.

[20] Zittermann A. Vitamin D in preventive medicine: are we ignoring the evidence, J Nutr 2003; 89: 552-572.

[21] Z Shi, Y Okuno, M Rifa'i, AT Endharti, K Akane, K Isobe, H Suzuki .2009. Human CD8+ CXCR3+ T cells have the same function as murine $\mathrm{CD} 8+$ CD122+Treg. European journal of immunology 39 (8), 2106-2119 